\title{
KONSEP MIKRO EKONOMI SYARIAH
}

\author{
Nikmatul Husna' ${ }^{1}$ Husni Thamrin ${ }^{2}$ \\ *1,2 Program Studi Ekonomi Syariah Program Pascasarjana \\ Universitas Islam Negeri Sultan Syarif Kasim Riau
}

Email: nikmatulhusna2603@gmail.com, husni2017husni@gmail.com

\begin{abstract}
Abstrak: Ekonomi Islam adalah sebuah sistem ilmu pengetahuan yang menyoroti masalah perekonomian sama seperti konsep ekonomi konvensional lainnya. Hanya dalam sistem ekonomi ini, nilai-nilai Islam menjadi landasan dan dasar dalam setiap aktifitasnya. Pada ekonomi mikro Islam menjelaskan bagaimana sebuah keputusan diambil oleh setiap unit ekonomi dengan memasukkan batasan-batasan syariah sebagai variabel yang utama. Dalam ekonomi mikro Islam, kita menganggap bahwa basic ekonomi (variabel-variabel ekonomi) hanya memenuhi segi necessary condition, sedangkan moral dan tatanan syariah akan memenuhi unsur sufficient condition dalam ruang lingkup pembahasan ekonomi mikro. Ekonomi Islam sebagai alternatif untuk memecahkan permasalahan ekonomi secara global dan untuk mencapai kebahagian spiritual karena aktifitas ekonominya dapat sekaligus bernilai sebagai ibadah.
\end{abstract}

Kata Kunci: Ekonomi Islam, Mikro Ekonomi Syariah. 


\section{PENDAHULUAN}

Ekonomi Islam adalah sebuah sistem ilmu pengetahuan yang menyoroti masalah perekonomian. Sama seperti konsep ekonomi konvensional lainnya. Hanya dalam sistem ekonomi ini, nilainilai Islam menjadi landasan dan dasar dalam setiap aktifitasnya. Pokok-pokok yang dianalisis dalam teori mikro ekonomi adalah bagaimanakah caranya menggunakan faktor-faktor produksi yang tersedia secara efisien agar kemakmuran masyarakat dapat dimaksimumkan. Analisis seperti ini dibuat berdasarkan kepada pemikiran bahwa kebutuhan dan keinginan manusia tidak terbatas, sedangkan kemampuan faktor-faktor produksi menghasilkan barang dan jasa untuk memenuhi kebutuhan dan keinginan masyarakat adalah terbatas.

Sebelum memahami teori ekonomi ekonomi mikro Islam, diperlukan untuk mengetahui rancang bangun ekonomi mikro Islam. Hal ini diperlukan agar mengetahui gambaran tentang landasanlandasan pada ekonomi mikro Islam. Landasan-landasan tersebut berpegang atas prinsip utama dalam syariah, sebab Tauhid adalah kunci keimanan dari seseorang. Dalam ekonomi Islam, setiap tindakan ekonomi pada manusia akan didasari oleh prinsip-prinsip yang sesuai dengan ajaran Islam. Oleh karena itu setiap tindakan yang menyimpang dari syariat akan dilarang, karena bisa menyebabkan kemudharatan bagi umat manusia.

Pada ekonomi mikro Islam menjelaskan bagaimana sebuah keputusan diambil oleh setiap unit ekonomi dengan memasukkan batasanbatasan syariah sebagai variabel yang utama. Dalam ekonomi mikro Islam, kita menganggap bahwa basic ekonomi (variabel-variabel ekonomi) hanya memenuhi segi necessary condition, sedangkan moral dan tatanan syari'ah akan memenuhi unsur sufficient condition dalam ruang lingkup pembahasan ekonomi mikro (Subagiyo, 2016).

Ekonomi Islam yang bersumber dari Al-Qur'an dan Hadits dan dikaji oleh para cendekiawan memiliki karakteristik, rancang bangun dan tujuan yang berbeda dengan ekonomi lainnya semisal ekonomi liberal atau sosial. Pengetahuan mengenai hal ini dirasa penting agar masyarakat semakin mengenal ekonomi Islam sebagai alternatif untuk memecahkan permasalahan ekonomi secara global dan untuk mencapai kebahagian spiritual karena aktifitas ekonominya dapat sekaligus bernilai sebagai ibadah.

\section{TINJAUAN PUSTAKA \\ Teori Mikro Ekonomi}

Teori mikro ekonomi atau ekonomi mikro boleh diartikan sebagai "ilmu ekonomi kecil". Berdasarkan kepada pola dan ruang lingkup analisisnya, teori mikro ekonomi dapat didefinisikan sebagai satu bidang studi dalam ilmu ekonomi yang menganalisis mengenai bagian-bagian kecil dari keseluruhan kegiatan perekonomian. Ekonomi mikro konvensional ini didasarkan pada perilaku individuindividu yang secara nyata terjadi disetiap unit ekonomi, prilaku individu dari setiap unit ekonomi tersebut akan bertindak dan berperilaku sesuai dengan norma dan aturan menurut persepsinya masing-masing. Pembahasan perilaku konsumsi ekonomi mikro konvensional hanya memperhatikan perubahan pada variabel ekonomi, seperti harga dan pendapatan.

Pokok-pokok yang dianalisis dalam teori mikro ekonomi tersebut adalah bagaimanakah caranya menggunakan faktor-faktor produksi yang tersedia

SYARIKAT : Jurnal Rumpun Ekonomi Syariah Volume 4, Nomor 2, Desember 2021 
secara efisien agar kemakmuran masyarakat dapat dimaksimumkan. Analisis seperti ini dibuat berdasarkan kepada pemikiran bahwa kebutuhan dan keinginan manusia tidak terbatas, sedangkan kemampuan faktor-faktor produksi menghasilkan barang dan jasa untuk memenuhi kebutuhan dan keinginan masyarakat adalah terbatas.

Dalam teori ekonomi masalah diatas dibagi dan dibedakan menjadi tiga persoalan yaitu: (1) apakah jenis-jenis barang dan jasa yang perlu diproduksikan? (2) bagaimanakah barang dan jasa yang diperlukan masyarakat akan dihasilkan? (3) untuk siapakah barang dan jasa perlu dihasilkan? (Ridwan, 2018).

Untuk memberi gambaran yang lebih jelas lagi mengenai corak kegiatan ekonomi yang wujud dalam suatu perekonomian, ahli-ahli ekonomi biasanya membuat suatu diagram yang dinamakan sirkulasi aliran pendapatan. Diagram itu memberi gambaran tentang aliran-aliran faktor-faktor produksi, pendapatan, barang-barang dan jasa-jasa dan pengeluaran, antara sektor-sektor dalam kegiatan ekonomi. Dalam sirkulasi aliran pendapatan yang sederhana dimisalkan bahwa pemerintah tidak wujud dan tidak melakukan campur tangan dalam kegiatan perekonomian.

Dengan demikian sirkulasi aliran pendapatan biasanya hanyalah menunjukkan bentuk aliran produksi, pendapatan, barang serta jasa dan pengeluaran, antara sektor rumah tangga dan sektor perusahaan. Misalkan pemerintah tidak melakukan kegiatan ekonomi dan tidak melakukan campur tangan apa pun dalam kegiatan ekonomi makan aliran faktor produksi, pendapatan, barang dan pengeluaran dalam suatu perekonomian dapat digambarkan dalam gambar dibawah ini:

Gambar 1. Sirkulasi Aliran Pendapatan

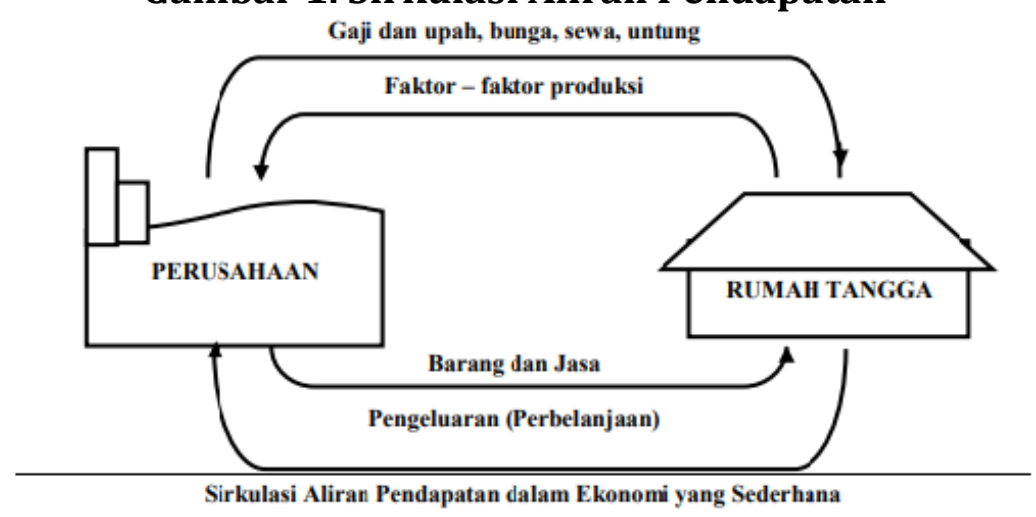

Dalam diagram tersebut, perekonomian dibedakan dalam dua sektor yaitu sektor perusahaan dan sektor rumah tangga. Sektor rumah tangga merupakan pemilik faktor-faktor produksi yang akan menawarkan sumbersumber daya kepada para pengusaha dan para pengusaha akan menyambut tawaran tersebut karena mereka memerlukan faktor-faktor produksi untuk memproduksi barang-barang dan jasajasa. Penawaran dan penggunaan faktorfaktor produksi tersebut akan mewujudkan dua macam aliran, yaitu aliran barang dan aliran uang. Keduanya terdapat pada bagian atas dari diagram yang ditunjukkan dalam gambar tersebut. Dapat dilihat bahwa sektor perusahaan akan memberikan pendapatan kepada berbagai jenis sumber daya ini, yaitu

SYARIKAT : Jurnal Rumpun Ekonomi Syariah Volume 4, Nomor 2, Desember 2021 
tenaga kerja mendapat upah dan gaji, tanah mendapat sewa, modal mendapat bunga dan keahlian keusahawanan mendapat keuntungan. Aliran dari berbagai jenis pendapatan dari sektor perusahaan ini adalah aliran dalam bentuk uang. Telah diterangkan bahwa kegiatan para pengusaha memproduksi barang dan jasa bukanlah untuk memenuhi kebutuhan mereka tetapi dengan tujuan untuk dijual dan mendapatkan untung. Rumah tangga adalah pembeli - pembeli barang dan jasa yang diproduksi sektor perusahaan. Berbagai jenis pendapatan yang diterima oleh faktor-faktor produksi yang dimiliki rumah tangga akan mereka gunakan untuk memperoleh barang dan jasa yang mereka butuhkan. Kecenderungan ini menyebabkan dalam perekonomian akan wujud dua aliran, yang pertama adalah pengeluaran konsumsi, yaitu pembelanjaan masyarakat dari sektor rumah tangga kesektor perusahaan. Aliran ini dalam bentuk uang. Aliran kedua adalah aliran barang, yaitu aliran barang-barang dan jasa-jasa dari sektor perusahaan ke sektor rumah tangga (Ridwan, 2018).

\section{Manfaat dan Batasan Teori Ekonomi Mikro Islam}

Pembahasan ekonomi mikro Islam tidak membedakan antara ilmu ekonomi sebagai analisis positif dan normatif. Yang dimaksud dengan analisis positif adalah analisis yang menjelaskan sebab akibat (Al-Faifi, 2009: 14).

Sedangkan analisis normative merupakan analisis yang menjelaskan tentang apa yang seharusnya berlaku. Faktanya, permasalahan ekonomi selalu dijelaskan dan diselesaikan dengan menggunakan beberapa asumsi yang sekiranya sesuai dengan kenyataannya. Memasukkan unsur asumsi berarti memasukkan pemikiran atau pendapat yang bersifat normatif.

Ilmu ekonomi islam hanya memandang permasalahan ekonomi digolongkan dalam 2 (dua), yaitu ilmu ekonomi (science of economics) dan doktrin ilmu ekonomi (doctrine of economics). Menurut Muhammad Baqir As-Sadr, perbedaan ekonomi islam dengan ekonomi konvensional terletak pada filosofi ekonomi, bukan pada ilmu ekonominya (Karim, 2015 : 30).

Ekonomi Islam adalah sebuah doktrin dan bukan suatu ilmu pengetahuan, karena ia adalah cara yang direkomendasikan Islam dalam mengejar kehidupan ekonomi, sedangkan ilmu ekonomi hanya menjelaskan bagaimana kegiatan ekonomi berlangsung. Integrasi antara ekonomi filosofi ke dalam ilmu ekonomi murni disebabkan adanya pandangan bahwa kehidupan di dunia tidak dapat dipisahkan dari kehidupan di akhirat. Semuanya harus seimbang karena kehidupan dunia adalah ladang bagi bekal kehidupan akherat (Ash-Shadr, 2008 : 13).

\section{Surplus Konsumen dan Surplus Produsen}

Surplus konsumen adalah keuntungan yang diperoleh konsumen karena membayar harga yang lebih rendah dari harga yang dapat mereka bayar. Atau selisih antara jumlah yang konsumen sedia bayarkan dengan yang harus dibayar. Surplus produsen merupakan keuntungan yang diperoleh produsen karena memperoleh harga yang lebih tinggi dari harga produsen bersedia untuk menjual. Atau selisih antara jumlah yang diterima dengan yang mereka harapkan untuk dibayar.

Surplus adalah keuntungan atas kelebihan dari yang diperkirakan. Konsumen mengalami surplus apabila 
harga yang dibayarkannya untuk mendapatkan sejumlah komoditi lebih rendah dari yang diperkirakan atau dari yang mampu dibayarkannya. Surplus Produsen terjadi jika harga yang disepakati dengan konsumen lebih tinggi dari harga yang seharusnya ia berikan pada konsumen. Surplus terbagi menjadi dua yaitu surplus nominal dan surplus dan riel. Surplus nominal adalah keuntungan kotor yang diperoleh konsumen atau produsen. Konsumen untung karena membayar kurang dari seharusnya dan produsen untung karena menerima lebih dari yang seharusnya.

Konsumen mendapatkan surplus bila harga yang diperkirakannya lebih tinggi dari harga keseimbangan pasar. Besarnya surplus bergantung pada berapa banyak jumlah kuantitas yang akan dibeli di kalikan dengan selisih harga. Produsen akan mendapatkan surplus jika harga jual produknya lebih rendah dari harga yang mampu dibeli oleh konsumen dalam kondisi keseimbangan pasar.

\section{Tas'ir (Penetapan Harga Dalam Islam)}

Tas'ir adalah penetapan harga baru bagi barang yang akan di jual (komoditi) dengan ketentuan bahwa si pemilik barang tidak merasa terzhalimi dan si pembeli tidak merasa keberatan (Al-Faifi, 2009 : 53).

Tas'ir secara etimologi kata at-tasir seakar dengan kata as-sir'r yang berarti penetapan harga. Sedangkan al-jabari berarti secara paksa. Dalam fiqih islam, ada dua istilah yang berbeda yang menyangkut harga suatu barang, yaitu ats-tsaman dan as-si'r. Ats-tsaman, menurut para ulama fiqh dalam patokan harga satuan barang, sedangkan as-si'r adalah harga yang berlaku secara aktual di pasar. Lebih lanjut, ulama fiqh menyatakan bahwa fluktuasi harga suatu komoditi berkaitan erat dengan as-si'r, bukan ats-tsaman (Haroen, 2000:13814).

Menurut Abd al-karim Usman, pakar Fiqh dari Mesir, dalam perilaku ekonomi, harga suatu komoditi akan stabil apabila stock barang tersedia barang di pasar, karena antara penyediaan barang dan dengan permintaan konsumen terdapat keseimbangan. Akan tetapi, apabila barang yang tersedia sedikit, sedangkan permintaaan konsumen banyak, maka dalam hal ini akan terjadi fluktuasi harga. Dalam keadaan yang di sebutkan terakhir ini, menurutnya, pihak pemerintah tidak boleh ikut campur dalam masalah harga itu. Cara yang boleh menstabilkan harga itu adalah pemerintah berupaya menyediakan komoditi di maksud dan menyesuaikannya dengan permintaan pasar. Sebaliknya, apabila stock barang banyak di pasar, tetapi harga tetap melonjak naik, maka pihak pemerintah perlu melakukan pengawasan yang ketat. Apabila kenaikan harga ini di sebabkan ulah para pedagang. Misalnya dengan melakukan penimbunan barang dengan tujuan menjualnya setelah melonjaknya harga (ikhtikar), maka dalam kasus seperti ini pemerintah berhak untuk menetapkan harga penetapan harga ini, dan fiqh, di sebut dengan at-tas'ir aljabari.

\section{Prinsip dan Tingkatan Konsumsi Dalam Islam}

Konsumsi dalam ekonomi Islam dapat didefenisikan dengan memakan makanan yang baik, halal dan bermanfaat bagi manusia, pemanfaatan segala anugerah Allah di muka bumi, atau sebagai sebuah kebajikan karena kenikmatan yang diciptakan Allah untuk manusia adalah wujud ketaatan kepadaNya. Namun ini tidak berarti seorang 
konsumen dapat mengkonsumsi segala barang yang dikehendaki, tanpa memperhatikan kualitas dan kemurniannya, atau mengkonsumsi sebanyak-banyaknya tanpa memperhatikan hak-hak orang lain yang ada di dalamnya. Oleh karena itu dalam konsumsi Islam, ada 5 prinsip dasar yang harus dijadikan sebagai acuan adalah: (Sumar'in, 2013 : 95)

1. Prinsip keadilan, Mengajarkan kebenaran kepada manusia untuk mempergunakan barang-barang yang dibenarkan oleh syara', baik dari segi zat, cara memproduksi, maupun tujuan dari mengkonsumsi tersebut. Dengan demikian dalam ekonomi islam barang-barang yang halal dari zatnya bisa saja menjadi haram ketika cara memproduksi dan tujuan mengkonsumsinya melanggar ketentuan syara'.

2. Prinsip kebersihan,

Berarti bahwa barang yang dikonsumsi harus bersih, baik, berguna dan sesuai untuk dimakan. Barang yang haram, kotor, bercampur najis dan bisa menimbulkan kemudaratan duniawi dan ukhrawi tidak boleh dipergunakan. Karena itu tidak semua diperkenankan untuk dikonsumsi.

3. Prinsip kesederhanaan,

Prinsip ini mengandung arti bahwa dalam melakukan konsumsi tidak boleh berlebih-lebihan. Prinsip ini menganjurkan agar konsumsi sampai tingkat minimum (standar) sehingga bisa mengekang hawa nafsu dan keinginan yang berlebihan, tidak terlalu kikir dan tidak berlebihan. Prinsip kesederhanaan juga mengajarkan kepada konsumen apabila pendapatan konsumen meningkat, pendapatan tersebut seharusnya tidak hanya dapat dipergunakan untuk meningkatkan volume konsumsi, namun untuk kesejahteraan sosial.

4. Prinsip kemurahan hati,

Dalam prinsip ini Islam memerintahkan kita agar senantiasa memperhatikan saudara dan tetangga.

5. Prinsip moralitas,

Prinsip menujukkan bahwa konsumsi harus dapat memenuhi etika, adat kesopanan dan perilaku terpuji seperti syukur, zikir,dan fikir serta sabar mengesampingkan sifatsifat tercela seperti kikir dan rakus.

\section{Prinsip Dan Tujuan Produksi Dalam Ekonomi Islam}

Tujuan kegiatan produksi adalah meningkatkan kemashlahatan yang bisa diwujudkan dalam berbagai bentuk di antaranya:

1. Pemenuhan kebutuhan manusia pada tingkatan manusia moderat. Hal ini akan menimbulkan dua implikasi yaitu pertama, produsen hanya menghasilkan barang dan jasa yang menjadi kebutuhan meskipun belum tentu keinginan konsumen, karena keinginan manusia sifatnya terbatas sehingga sering kali mengakibatkan ketidakjelasan antara keinginan dan apa yang benar-benar menjadi kebutuhan hidup.

2. Menemukan kebutuhan manusia dan pemenuhannya. Meskipun produsen hanya menyediakan sarana kebutuhan manusia, namun hal ini bukan berarti produsen bersifat rasis dan reaktif terhadap kebutuhan manusia yang mau memproduksi berdasarkan 
permintaan konsumen. Produsen harus mampu menjadi sosok yang kreatif, proaktif dan inovatif dalam menemukan barang dan jasa apa yang menjadi kebutuhan manusia dan kemudian memenuhi kebutuhan tersebut. Penemuan ini kemudia di sosialisasikan kepada konsumen sehingga konsumen mengetahuinya.

3. Menyiapkan persediaan barang dan jasa di masa depan. Berorientasi ke masa depan berarti produsen harus terus meneruskan berupaya meningkatkan kualitas barang yang dihasilkan melalui proses riset dan pengembangan dan berkreasi untuk menciptakan barang-barang baru yang lebih menarik dan dinikmati masyarakat.

4. Keperluan generasi yang akan datang. Islam menganjurkan umatnya untuk memperhatikan keperluan generasi yang akan datang. Produksi dilakukan tidak boleh mengganggu keberlanjutkan hidup genersi yang akan datang, pemanfaatan input dimasa sekarang tidak boleh menyebabkan generasi akan datang kesulitan dalam mengakses sumber tersebut, produksi yang dilakukan saat ini memiliki kaitan yang erat dengan kemampuan produksi di masa depan.

5. Keperluan sosial dan infaq di jalan Allah. Ini merupakan insentif utama bagi produsen untuk menghasilkan tingkat output yang lebih tinggi, yaitu memenuhi tanggung jawab sosial terhadap masyarakat. Walaupun keperluan pribadi, masyarakat, keperluan generasi sekarang dan generasi yang akan datang telah terpenuhi, produsen tidak harus bermalas-malasan dan berhenti berinovasi, tetapi sebaliknya, memproduksi lebih banyak lagi supaya dapat diberikan kepada masyarakat dalam bentuk zakat, sedekah, infaq, dan sebaliknya (Al-Arif, 2010 :153-154).

\section{Pasar Persaingan Sempurna Menurut Perspektif Islam}

Menurut Islam struktur pasar yang ideal terjadi, dimana penentuan harga sepenuhnya ditentukan oleh tarikan permintaan dan penawaran di pasar, tidak ada intervensi pasar. Rasulullah Saw sangat menjunjung tinggi pembentukan harga yang terjadi akibat pembentukan mekanisme pasar yang terjadi. Apabila Adam Smith mengatakan bahwasanya mekanisme pasar terjadi oleh adanya invisible hand (tangan-tangan ghaib) sebenarnya yang dikatakan tersebut terinspirasi oleh pemikiran ekonom Muslim terdahulu. Namun, struktur pasar persaingan sempurna tidaklah mungkin dapat terjadi dalam kehidupan nyata meskipun baik dalam ekonomi konvensional, maupun Islam keduanya mengatakan bahwa struktur persaingan sempurna merupakan struktur pasar yang paling baik dibandingkan dengan struktur pasar yang lainnya.

\section{Pasar Monopolistik Menurut Perspektif Islam}

Monopoli secara harfiah berarti di pasar hanya ada satu penjual. Frank Fisher menjelaskan kekuatan monopoli sebagai "the ability to act in unconstrained way" (kemampuan bertindak dalam menentukan harga dengan caranya sendiri), Pandangan Islam terhadap keberadaan satu penjual di pasar (pasar monopoli), atau tidak adanya pesaing, atau kecilnya persaingan di pasar, bukanlah suatu hal yang terlarang. Namun perlu diketahui bahwa Islam tidak 
membolehkan adanya ihtikhar. Ihtikhar adalah mengambil keuntungan di atas keuntungan normal dengan cara menjual lebih sedikit barang untuk harga yang lebih tinggi. Secara lebih spesifik mazhab Syafi'i dan Hanbali mendefinisikan ihtikar sebagai: "Menimbun barang yang telah dibeli pada saat harga bergejolak tinggi untuk menjualnya dengan harga yang lebih tinggi pada saat dibutuhkan oleh penduduk setempat atau lainnya" (Karim, $2010: 173-174$ ).

\section{METODE PENELITIAN}

Metode yang digunakan dalam penelitian ini adalah studi literatur atau penelitian kepustakaan. Studi literatur adalah ringkasan tertulis mengenai artikel dari jurnal, buku, dan dokumen lain yang mendeskripsikan teori serta informasi baik masa lalu maupun saat ini mengorganisasikan pustaka ke dalam topik dan dokumen yang dibutuhkan dilakukan dengan cara mempelajari referensi-referensi buku, artikel, jurnal dan browsing internet. Pengumpulan data dengan memanfaatkan daftar pustaka ini adalah agar dapat lebih mendukung objek suatu penelitian (Fathurrahman, 2011:31).

\section{SIMPULAN}

Sistem ekonomi adalah satu kesatuan mekanisme dan lembaga pengambilan keputusan yang mengimplementasikan keputusan terhadap produksi, distribusi dan konsumsi dalam suatu daerah atau wilayah. Terdapat banyak faktor yang membentuk suatu sistem ekonomi, seperti ideologi, nilai-nilai yang dianut, kebudayaan, sistem politik, keadaan alam, sejarah dan lain-lain. Sistem ekonomi juga didasarkan pada pemikiran, konsep, atau teori-teori ekonomi tertentu yang diyakini kebenarannya. Ekonomi Islam atau ekonomi yang berbasis syariah belakangan ini semakin diminati. Ekonomi Islam yang bersumber dari $\mathrm{Al}$ Qur'an dan Hadits dan dikaji oleh para cendekiawan memiliki karakteristik, rancang bangun dan tujuan yang berbeda dengan ekonomi lainnya semisal ekonomi liberal atau sosial. Pengetahuan mengenai hal ini dirasa penting agar masyarakat semakin mengenal ekonomi Islam sebagai alternatif untuk memecahkan permasalahan ekonomi secara global dan untuk mencapai kebahagian spiritual karena aktifitas ekonominya dapat sekaligus bernilai sebagai ibadah.

\section{DAFTAR RUJUKAN}

Al Arif, M. Rianto. (2010). Teori Mikro Ekonomi. Jakarta: Prenada Media.

Al-Faifi, Syaikh Sulaiman Ahmad Yahya. (2009). Fikih Sunnah Sayyid Sabiq. Jakarta: Pustaka Al-Kautsar.

Ash-Shadr, Muhammad Baqir. (2008). Iqtishduna: Our Economics, terjemahan Yudhi, Buku Induk Ekonomi Islam. Jakarta: Zahra Publishing House.

Fathurrahman, P. (2011). Metode Penelitian Pendidikan. Bandung: Pustaka Setia.

Haroen, Nasrun. (2000). Fiqh Muamalah. Jakarta: Gaya Media Pratama.

Karim, Adiwarman A. (2010). Ekonomi Mikro Islam. Jakarta: PT.Raja Grafindo Persada.

Karim, Adiwarman A. (2015). Ekonomi Mikro Islami. Jakarta: PT.Raja Grafindo Persada.

Ridwan, M, et.al. (2018). Ekonomi Mikro Islam. Buku Diktat, Universitas Islam Negeri Sumatera.

Subagiyo, Rokhmat. (2016) Ekonomi Mikro Islam. Jakarta: Alim's Publishing. 
Sumar'in. (2013). Sebuah Pendekatan

Ekonomi Mikro Perspektif Islam,

Yogyakarta: Graha Ilmu.

SYARIKAT : Jurnal Rumpun Ekonomi Syariah Volume 4, Nomor 2, Desember 2021 